\title{
Glucose transporters and enzymes related to glucose synthesis in small intestinal mucosa of mid-lactation dairy cows fed 2 levels of starch
}

\author{
A.-K. Lohrenz, ${ }^{\star}$ K. Duske, ${ }^{\star}$ U. Schönhusen, ${ }^{\star}$ B. Losand,† H. M. Seyfert, ${ }^{\star}$ C. C. Metges, ${ }^{*}$ and H. M. Hammon ${ }^{\star 1}$ \\ *Leibniz Institute for Farm Animal Biology (FBN), 18196 Dummerstorf, Germany \\ †State Institute of Animal Production, 18196 Dummerstorf, Germany
}

\section{ABSTRACT}

Diets containing corn starch may improve glucose supply by providing significant amounts of intestinal starch and increasing intestinal glucose absorption in dairy cows. Glucose absorption in the small intestine requires specific glucose transporters; that is, sodiumdependent glucose co-transporter-1 (SGLT1) and facilitated glucose transporter (GLUT2), which are usually downregulated in the small intestine of functional ruminants but are upregulated when luminal glucose is available. We tested the hypothesis that mRNA and protein expression of intestinal glucose transporters and mRNA expression of enzymes related to gluconeogenesis are affected by variable starch supply. Dairy cows ( $\mathrm{n}=9$ /group) were fed for $4 \mathrm{wk}$ total mixed rations (TMR) containing either high (HS) or low (LS) starch levels in the diet. Feed intake and milk yield were measured daily. After slaughter, tissue samples of the small intestinal mucosa (mid-duodenum and mid-jejunum) were taken for determination of mRNA concentrations of SGLT1 and GLUT2 as well as pyruvate carboxylase, cytosolic phosphoenolpyruvate carboxykinase, and glucose-6-phosphatase by real-time reverse transcription PCR relative to a housekeeping gene. Protein expression of GLUT2 in crude mucosal membranes and of SGLT1 and GLUT2 in brush-border membrane vesicles was quantified by sodium dodecyl sulfate-PAGE and immunoblot. A mixed model was used to examine feeding and time-related changes on feed intake and milk yield and to test feeding and gut site effects on gene or protein expression of glucose transporters and enzymes in the intestinal mucosa. Dry matter intake, but not energy intake, was higher in cows fed HS compared with LS. Abundance of SGLT1 mRNA tended to be higher in duodenal than in jejunal mucosa, and mRNA abundances of pyruvate carboxylase tended to be higher in jejunal than in duodenal mucosa. In brush-

Received March 3, 2011.

Accepted May 22, 2011.

${ }^{1}$ Corresponding author: hammon@fbn-dummerstorf.de border membrane vesicles, SGLT1 and GLUT2 protein expression could be demonstrated. No diet-dependent differences were found concerning mRNA and protein contents of glucose transporter or mRNA level of gluconeogenic enzymes. In conclusion, our investigations on glucose transporters and gluconeogenic enzymes in the small intestinal mucosa of dairy cows did not show significant diet regulation when TMR with different amounts of intestinal starch were fed. Therefore, predicted intestinal glucose absorption after enhanced starch feeding is probably not supported by changes of intestinal glucose transporters in dairy cows.

Key words: dairy cow, glucose transporter, intestinal mucosa

\section{INTRODUCTION}

Glucose uptake in dairy cows differs from that in monogastric animals mostly due to the extensive starch degradation and subsequent VFA absorption in the rumen (Nocek and Tamminga, 1991; Huntington, 1997; Matthé et al., 2000). However, diets typically used for high-yielding dairy cows contain high amounts of starch that are not completely degraded in the rumen, especially when corn silage and corn starch are fed (Nocek and Tamminga, 1991; Breves and Wolffram, 2006; Reynolds, 2006). Starch digestion and glucose absorption in the small intestine may contribute to glucose supply in dairy cows, and the extent and importance of glucose uptake by the small intestine has been discussed previously (Matthé et al., 2000; Reynolds, 2006; Nozière et al., 2010). Importantly, ruminants are able to adapt their capacity for intestinal glucose uptake by increasing the number of glucose transporters, especially sodium-dependent glucose transporter 1 (SGLT1), when increasing amounts of glucose pass the rumen and reach the duodenum (Shirazi-Beechey et al., 1995; Dyer et al., 2003). However, it is not known whether this is of practical relevance in dairy cows when a significant amount of rumen-undegraded starch is available in the small intestine.

Besides SGLT1, the facilitative glucose transporter 2 (GLUT2) is involved in intestinal glucose absorption 
in dairy cows (Mills et al., 1999). Whereas SGLT1 is localized at the luminal site, GLUT2 was thought to be positioned on the basolateral membrane to facilitate glucose transport into the bloodstream (Breves and Wolffram, 2006). However, recent findings support the concept of rapid trafficking of GLUT2 to the apical membrane, and GLUT2 has been detected in brushborder membrane vesicles (BBMV) of several species including sheep (Kellett et al., 2008). This trafficking occurs mainly during elevated substrate flow to enable rapid glucose absorption in the small intestine (Kellett et al., 2008). It is conceivable that apical GLUT2 also exists in small intestinal epithelia of dairy cows, but this has not yet been shown.

Besides the discussion on relevance of intestinal starch digestion and glucose absorption on energy supply in dairy cows, the fate of absorbed glucose in the intestinal mucosa is also not clear. Portal-drained glucose flux significantly increased in sheep after feeding a corn-based diet (Janes et al., 1985) and in cows when glucose was infused into the abomasum (Larsen and Kristensen, 2009). However, portal-drained glucose flux was lower when starch instead of glucose was infused and depended on starch source and route of starch infusion (Reynolds, 2006). In addition, enterocytes of the small intestine and possibly of the large intestine as well as rumen epithelial cells may utilize additional glucose. Data concerning enteral glucose metabolism are inconsistent (Okine et al., 1995; Matthé et al., 2000; Reynolds, 2006) and results may depend on available metabolic substrates (Oba et al., 2004), but studies on the fate of enteral glucose in dairy cows are rare. However, utilization of additional luminal glucose should affect glucose metabolism in enterocytes. In addition, recent findings on gluconeogenic activity in the intestine (Mithieux, 2005; Battezzati, 2010) may raise the interest in intestinal gluconeogenesis in ruminants, especially in high-yielding dairy cows, where huge amounts of glucose are needed for milk production (Drackley et al., 2001).

Because glucose metabolism in the small intestinal mucosa depends strongly on the type of energy source, we have investigated intestinal glucose metabolism in dairy cows fed either a high starch (HS) or a low starch (LS) diet where a significant amount of starch was replaced with rumen-protected fat. These different diets affected systemic and hepatic glucose metabolism (Hammon et al., 2008; Lohrenz et al., 2010). We hypothesized that the different starch diets affect gene and protein expression of SGLT1 and GLUT2 as well as gene expression of enzymes involved in glucose metabolism in intestinal mucosa.

\section{MATERIALS AND METHODS}

\section{Animals, Husbandry, and Feeding}

The experimental protocol was approved by the relevant authorities (Landesamt für Landwirtschaft, Lebensmittelsicherheit und Fischerei MecklenburgVorpommern). Eighteen German Holstein cows, with comparable milk production (first lactation $>9,000 \mathrm{~kg}$ of milk in $305 \mathrm{~d}$ ), were investigated during the second lactation. Before starting this study, cows passed through a study with different feeding during the dry period but the same lactation diet after parturition up to 98 DIM (Duske et al., 2009). From wk 15 to 18 in lactation, cows were fed TMR containing starch either on a high (HS) or low (LS) level. For logistic reasons, 3 cows in each group (total of 6 cows) were investigated during the same period (block). Ingredients and chemical composition of the different diets were published recently in a companion paper (Lohrenz et al., 2010) and are shown in Table 1. Diets were formulated to be isoenergetic, and fat was added at the expense of starch. The starch content in the HS diet was consistent with TMR usually fed to dairy cows in eastern Germany (Hammon et al., 2009) and reflected the recommendations of the German Society for Nutrition Physiology (2001), whereas starch content in the LS diet was half of that amount. Allocation of cows to feeding groups ( $\mathrm{n}=9$ /group) corresponded to the respective feeding during the dry period (Duske et al., 2009). Cows of the HS and LS groups did not differ with regard to BW or back fat thickness (Duske et al., 2009).

The rumen-protected fat (Hajenol; Harles und Jentzsch GmbH, Uetersen, Germany) used consisted of Ca-salts with mainly palmitic and oleic acids, and its apparent digestibility was $78.3 \%$ (Voigt et al., 2006). Diets were fed ad libitum at 0600 and $1500 \mathrm{~h}$, and cows were milked twice daily at 0500 and $1600 \mathrm{~h}$. They were housed in a freestall barn with individual troughs placed on scales (Bayerische Landesanstalt für Landwirtschaft, Institut für Landtechnik, Bauwesen und Umwelttechnik, Freising, Germany) to monitor individual feed intake. Cows had free access to water.

\section{Analyses in Feed and Milk}

Dry matter, crude fat, starch, and crude fiber of freeze-dried dietary components and TMR were determined according to the Weender standard procedure (Naumann and Bassler, 1993). Nitrogen was determined by combustion analysis (CNS-2000, Leco Corp., St. Joseph, MI), and CP was then calculated by mul- 
Table 1. Ingredients and chemical composition of high starch (HS) and low starch (LS) diets

\begin{tabular}{|c|c|c|}
\hline \multirow[b]{2}{*}{ Item } & \multicolumn{2}{|c|}{ Group } \\
\hline & HS & LS \\
\hline \multicolumn{3}{|l|}{ Ingredient, $\mathrm{g} / \mathrm{kg}$ of $\mathrm{DM}$} \\
\hline Corn silage & 272 & 290 \\
\hline Grass silage & 250 & 277 \\
\hline Hay & 32 & 34 \\
\hline Dried pulp & 106 & 155 \\
\hline Corn starch & 127 & - \\
\hline Rumen-protected fat ${ }^{1}$ & - & 57 \\
\hline Soybean meal & 95 & 67 \\
\hline Protected soybean $^{2}$ & 49 & 52 \\
\hline Barley meal & 48 & 51 \\
\hline Urea & 3 & 4 \\
\hline Minerals/vitamins & 13 & 13 \\
\hline Limestone & 5 & - \\
\hline \multicolumn{3}{|l|}{ Chemical analyses, per $\mathrm{kg}$ of DM } \\
\hline $\mathrm{CP}, \mathrm{g}$ & 170 & 185 \\
\hline Utilizable protein ${ }^{3} \mathrm{~g}$ & 162 & 169 \\
\hline Crude fiber, $g$ & 163 & 182 \\
\hline Starch, g & 240 & 120 \\
\hline Rumen-undegraded starch, ${ }^{3} \mathrm{~g}$ & 80 & 18 \\
\hline Crude fat, $g$ & 22 & 60 \\
\hline $\mathrm{NE}_{\mathrm{L}}{ }^{3} \mathrm{MJ}$ & 7.04 & 7.56 \\
\hline
\end{tabular}

${ }^{1}$ Hajenol (Harles und Jentzsch GmbH, Uetersen, Germany) contained $840 \mathrm{~g} / \mathrm{kg}$ of DM crude fat (1.5\% myristic acid, $44 \%$ palmitic acid, $5 \%$ stearic acid, $40 \%$ oleic acid, and $9.5 \%$ linoleic acid), $20.2 \mathrm{MJ}$ of $\mathrm{NE}_{\mathrm{L}} /$ $\mathrm{kg}$ of DM, $120 \mathrm{~g} / \mathrm{kg}$ of DM crude ash, and $95 \mathrm{~g} / \mathrm{kg}$ of DM calcium.

${ }^{2}$ Byoprofin (Wulfa-Mast GmbH, Dinklage, Germany); protection of extracted soybean meal was through formaldehyde treatment.

${ }^{3}$ German Society of Nutrition Physiology (2001).

tiplying the $\mathrm{N}$ content by 6.25 . Utilizable protein and $\mathrm{NE}_{\mathrm{L}}$ in the diets were calculated according to German Society of Nutrition Physiology (2001). Ruminally undegraded starch was calculated according to Deutsche Landwirtschafts-Gesellschaft (DLG, 2008).

\section{Intestine Tissue Sampling and Analyses}

mRNA Analyses in Duodenal and Jejunal Mucosa. Cows were slaughtered at the end of the feeding experiment and tissue samples were taken from mid-duodenum and mid-jejunum. For mRNA measurements, mucosa was scraped off with a microscope slide, snap-frozen in liquid nitrogen, and stored at $-80^{\circ} \mathrm{C}$ un- til analyzed. Freeze-dried mucosa samples were ground in liquid nitrogen immediately before analysis. Total RNA was extracted using TRIzol Reagent (Invitrogen, Karlsruhe, Germany) and resuspended in RNase-free water. The integrity and purity of RNA were tested by measurement of optical density (ratios at 260 and 280 $\mathrm{nm}$ being greater than 1.9) and by electrophoresis using ethidium bromide staining. A total of $1 \mu \mathrm{g}$ of RNA was reverse-transcribed into cDNA using random primers (Random Primers, Invitrogen) and purified using the High Pure PCR Product Purification Kit (Roche Diagnostics, Mannheim, Germany; Hammon et al., 2009).

Real-time reverse transcription (RT)-PCR was performed by LightCycler (Roche Molecular Biochemicals, Mannheim, Germany) using SYBR Green I as fluorescence dye (Hammon et al., 2009). Specific primers were used to measure the mRNA concentrations of SGLT1, GLUT2, cytosolic phosphoenolpyruvate carboxykinase (PEPCK; EC 4.1.1.32), pyruvate carboxylase (PC; EC 6.4.1.1), glucose-6-phosphatase (G6Pase; EC 3.1.3.9), and $\beta$-actin. Primers used for PCR measurement of PEPCK, PC, G6Pase, GLUT2 were published recently (Hammon et al., 2009). Sequences of SGLT1 and bovine $\beta$-actin are listed in Table 2 . Primers were designed to flank a region that contains at least one intron to ensure that no contaminating genomic DNA was amplified that could lead to false signals.

Melting temperatures that were performed by the LightCycler in a melting curve analysis program after the last amplification cycle demonstrated specific PCR products. Upon agarose gel electrophoresis, all PCR products moved in one single band and showed the expected size (Table 2; Hammon et al., 2009). Products for SGLT1 and $\beta$-actin were verified by sequencing using an ABI Sequencing kit (ABI Big Dye Terminator, Applied Biosystems, Darmstadt, Germany) and an ABI 310 Genetic Analyzer (Applied Biosystems, Darmstadt, Germany).

Quantification of mRNA was performed by relative expression using $\beta$-actin as reference gene transcript (Pfaffl, 2001). For all samples, crossing point (Ct) values, which represent the intersection of a fixed threshold above background fluorescence and the amplification

Table 2. Primers used for real-time reverse-transcription PCR to analyze mRNA concentrations of sodiumdependent glucose co-transporter-1 (SGLT1) and $\beta$-actin in the small intestine

\begin{tabular}{|c|c|c|c|c|}
\hline Primer $^{1}$ & Primer sequence $5^{\prime} \rightarrow 3^{\prime}$ & $\begin{array}{l}\text { Coding } \\
\text { sequence }\end{array}$ & $\begin{array}{l}\text { Length, } \\
\text { bp }\end{array}$ & $\begin{array}{l}\mathrm{NCBI}^{2} \\
\text { accession no. }\end{array}$ \\
\hline SGLT1 for & CAGTCAGCACAGAGTGGACAG & 1,352 to 1,372 & 308 & NM_174606 \\
\hline SGLT1 rev & AAGAGGGAGACAGCCAGGAT & 1,640 to 1,659 & & \\
\hline$\beta$-actin for & ATCACCATCGGCAATGAGC & 781 to 799 & 331 & AY141970 \\
\hline$\beta$-actin rev & TGATCCACATCTGCTGGAAG & 1,092 to 1,111 & & \\
\hline
\end{tabular}


curve (Rasmussen, 2001), were determined for each target gene and for $\beta$-actin. Values of $\mathrm{Ct}$ for target genes and for $\beta$-actin were corrected for different runs by an internal standard $(\Delta \mathrm{Ct})$. For each sample, $\Delta \mathrm{Ct}_{\beta \text {-actin }}$ was used for normalization of the amount of every target gene $\left(\Delta \mathrm{Ct}_{\text {target }}\right)$ of the corresponding sample, which resulted in $\Delta \Delta \mathrm{Ct}\left(\Delta \mathrm{Ct}_{\text {target }}-\Delta \mathrm{Ct}_{\beta \text {-actin }}\right)$. Relative expression levels $(\mathrm{R})$ within each enzyme were given by the arithmetic equation $\mathrm{R}=2^{-\Delta \Delta \mathrm{Ct}}$ (Pfaffl, 2001). The $\operatorname{logarithm}(\log 2)$ is based on an optimum efficiency (E) of $\mathrm{PCR}$, which is $\mathrm{E}=2$, when the $\mathrm{PCR}$ product is replicated in every cycle. The PCR efficiency (E) was calculated based on the slope calculated by LightCycler software 4.05 (Roche Applied Science, Mannheim, Germany) using the equation $\mathrm{E}=10[-1$ /slope]. Efficiency of PCR was 1.7 to 1.9 , and was therefore close to 2 . Based on $\Delta \mathrm{Ct}$ evaluation, expression of $\beta$-actin in our study was not affected by diet or intestinal segment. Inter- and intraassay CV for RT-PCR of target and reference genes were below $1 \%$.

Preparation of Brush-Border Membrane Vesicles. Brush-border membrane vesicles (BBMV) were prepared by a modification of the $\mathrm{Mg}^{2+}$-EGTA precipitation method and sequential centrifugation as described by Schröder and Breves (1996). Frozen intestinal tissue samples $(7-10 \mathrm{~g})$ were thawed on ice. Epithelial cells were harvested after 10 min vibration with a Vibrax mixer (Jahnke und Kunkel, Staufen, Germany) in $10 \mathrm{~mL}$ of Tris-HCl buffer $(12 \mathrm{~m} M, \mathrm{pH} 7.4)$ with 300 $\mathrm{m} M$ mannitol, and $5 \mathrm{~m} M$ EGTA. The cell suspensions were diluted with a 5 -fold amount of ice-cold water and homogenized with an Ultra Turrax T 25 homogenizer $(13,500 \mathrm{U} / \mathrm{min})$. After removal of the foam, $\mathrm{MgCl}_{2}$ (Backer, Deventer, the Netherlands) was added to a final concentration of $10 \mathrm{~m} M$. The solution was kept on ice for $15 \mathrm{~min}$ and centrifuged $(3,000 \times g, 15 \mathrm{~min}$ at $\left.4^{\circ} \mathrm{C}\right)$. The supernatant was centrifuged $(27,500 \times g, 30$ min at $4^{\circ} \mathrm{C}$ ) and the resulting pellet was resuspended in $10 \mathrm{~mL}$ of Tris- $\mathrm{HCl}$ buffer $(12 \mathrm{~m} M, \mathrm{pH}$ 7.4) with 60 $\mathrm{m} M$ mannitol and $5 \mathrm{~m} M$ EGTA with 10 strokes in a homogenizer (1.600 U/min, Potter-Elvehjem S 30, Braun, Melsungen, Germany). Precipitation of membranes by $\mathrm{MgCl}_{2}$ addition and the 2-step centrifugation procedure were repeated. The resulting pellet was suspended with a homogenizer, as described, in $20 \mathrm{~mL}$ of BBMV buffer (0.01 $\mathrm{m} M$ HEPES, $1 M$ Tris, $0.1 \mathrm{~m} M \mathrm{KCl}$, $\mathrm{pH}$ 7.4) with $100 \mathrm{~m} M$ mannitol. This suspension was centrifuged $\left(27,500 \times g, 40 \mathrm{~min}, 4^{\circ} \mathrm{C}\right)$, and the final pellet was resuspended in 0.7 to $3 \mathrm{~mL}$ of BBMV buffer by passing the mixture 10 times through a needle $(0.45 \times 25 \mathrm{~mm})$. The final protein concentration in BBMV was 10 to $20 \mathrm{mg} / \mathrm{mL}$. Portions $(200 \mu \mathrm{L})$ of BBMV were frozen in liquid nitrogen and stored until analyzed. Purity of BBMV was determined by marker enzyme assays. The activities of alkaline phosphatase (AP, EC3.1.3.1; kit no. 816388, Roche Diagnostics, Mannheim, Germany) and ouabain-sensitive $\mathrm{Na}^{+}-\mathrm{K}^{+}$-activated ATPase $\left(\mathrm{Na}^{+}-\right.$ $\mathrm{K}^{+}$-ATPase, EC 3.6.1.3; Fujita et al., 1971) were used as markers of the brush-border and basolateral membrane (Moe et al., 1985), respectively. On a protein basis, the enrichment of AP was 13 to 16 times and that of $\mathrm{Na}^{+} / \mathrm{K}^{+}$-ATPase was $1.4 \pm 0.4$ times greater in BBMV suspensions than in the corresponding homogenates, indicating satisfactory concentrations of brush border membrane in final BBMV preparations (Schröder and Breves, 1996). Protein concentrations of BBMV were determined according to the Bradford (1976) method with BSA (Sigma-Aldrich Co., St. Louis, MO) as standard.

Preparation of Crude Cell Membranes. Mucosal tissue $(4 \mathrm{mg})$ was homogenized at $4^{\circ} \mathrm{C}$ using an Ultra Turrax T $25(16,000 \mathrm{U} / \mathrm{min})$ for $3 \times 5 \mathrm{~s}$ in $8 \mathrm{~mL}$ of Tris- $\mathrm{HCl}$ buffer (12 mM, pH 7.4) with $300 \mathrm{~m} M$ mannitol and $5 \mathrm{~m} M$ EGTA. After removal of the foam, the homogenate was centrifuged at $800 \times g\left(5 \mathrm{~min}\right.$ at $\left.4^{\circ} \mathrm{C}\right)$. The pellet was discarded and the supernatant was centrifuged at $10,000 \times g\left(10 \mathrm{~min}\right.$ at $\left.4^{\circ} \mathrm{C}\right)$, and thereafter the new pellet was discarded and the supernatant was centrifuged at $100,000 \times g\left(1 \mathrm{~h}\right.$ at $\left.4^{\circ} \mathrm{C}\right)$. The resulting pellet was collected and resuspended in $1 \mathrm{~mL}$ of Tris$\mathrm{HCl}$ buffer $(12 \mathrm{~m} M$, pH 7.4) with $60 \mathrm{~m} M$ mannitol and $5 \mathrm{~m} M$ EGTA with 10 strokes in a homogenizer $(1.600$ U/min, Potter-Elvehjem S 30, Braun). Concentrations of protein in crude membrane preparations were determined as described above.

Measurements of SGLT1 and GLUT2 Protein. Protein expression of SGLT1 in BBMV (Zhao et al., 1998) as well as that of GLUT2 in BBMV and cell crude membranes was quantified by SDS-PAGE and immunoblot analyses. The BBMV samples $(21 \mu \mathrm{g}$ of protein for SGLT1 and $25 \mu \mathrm{g}$ of protein for GLUT2) and crude membrane samples (50 $\mu \mathrm{g}$ of protein for GLUT2) were separated by SDS-PAGE on 7.5\% acrylamide gels under reducing conditions (Laemmli, 1970) using a Mini Protean Electrophoresis System (Bio-Rad Laboratories GmbH, München, Germany). Protein markers (Precision Plus Protein, Bio-Rad Laboratories $\mathrm{GmbH}$ ) were used as molecular mass standard. Following electrophoresis, proteins were transferred onto nitrocellulose membrane (GE Healthcare, Buckinghamshire, UK). After blocking with Tris-buffered saline-Tween $(20 \mathrm{mM}$ Tris-HCl, pH 7.6, $137 \mathrm{mM} \mathrm{NaCl}$, and $50 \mathrm{~mL} / \mathrm{L}$ Tween 20) containing $0.5 \%$ nonfat dry milk powder (Carl Roth $\mathrm{GmbH}$, Karlsruhe, Germany), membranes were incubated overnight at $4^{\circ} \mathrm{C}$ with SGLT1 antibody $(1: 1,000$, Biotrend, Köln, Germany) or with GLUT2 antibody (1:750, Biotrend), respectively. The primary antibody used for SGLT1 was a polyclonal antibody raised in 
rabbits to a synthetic peptide corresponding to residues 402 to 419 of rabbit sequence. The primary antibody used for GLUT2 was a polyclonal antibody raised in rabbits to a synthetic peptide corresponding to amino acids 55 to 67 of the native molecule. Membranes were then washed with Tris-buffered saline-Tween $(1 \times 15$ min; $2 \times 15 \mathrm{~min}$ ) and were visualized with chemiluminescence (ECL Western Blotting Analysis System, GE Healthcare) by incubating for $1 \mathrm{~h}$ at room temperature with horseradish peroxidase-conjugated sheep antirabbit IgG (1:10,000, Serotec, Oxford, UK). The blot was autoradiographed (Hyperfilm ECL, Amersham Bioscience, Buckinghamshire, UK) and quantified by scanning densitometry (version 4.0, Molecular Imaging Systems, Eastman Kodak Company, Rochester, NY). Data were normalized to control preparations and reported as relative (arbitrary) units.

\section{Statistical Analyses}

Statistical analyses were done with the SAS System for Windows, release 9.1.3 (SAS Institute, 2004). Data are given as LSM \pm pooled SEM. Milk performance, DMI, and nutrient intake as well as measurements in the intestine were assessed by repeated-measures ANOVA using the MIXED procedure. The ANOVA model used for milk performance and feed intake contained the fixed effects diet (groups: HS, LS), time, and block $(1,2,3)$; the interactions between diet, time, and block during the 4-wk experiment; and a random cow effect. The ANOVA model used for measures in the gut contained the fixed effects of diet (groups: HS, LS), gut (intestinal segment), and block $(1,2,3)$; the interactions between diet, gut, and block; and a random cow effect. Additionally, all pairwise differences of these LSM were tested using the Tukey-Kramer procedure. Differences with $P \leq 0.1$ were considered as trends and with $P<0.05$ as significant. Because milk yield was higher in HS than in LS before the start of the experiment (Duske et al., 2009), milk yield at 98 DIM was included as co-variable into the model to adjust milk performance data.

\section{RESULTS}

\section{Feed Intake and Milk Performance}

A slight increase $(P<0.1)$ of DMI and energy intake occurred during the 4 -wk experimental period, and DMI, but not energy intake, was higher $(P<0.01)$ in HS than in LS (Table 3). Intake of crude and utilizable protein tended to increase $(P<0.1)$ with time, and utilizable protein intake tended to be higher $(P<0.1)$ in HS than in LS. A trend was observed for increasing starch and fat intake with time $(P<0.1)$. As planned, starch and especially ruminal undegraded starch intake was higher $(P<0.001)$ in HS, whereas fat intake was higher $(P<0.001)$ in LS. During the 4 wk of the experiment, milk yield was not affected by diet (mean: $30.6 \pm 0.5 \mathrm{~kg} / \mathrm{d})$.

\section{Expression of Glucose Transporters and Gluconeogenic Enzymes in the Small Intestine}

Specific mRNA for SGLT1 and GLUT2 mRNA were found in intestinal mucosa of duodenum and jejunum in dairy cows. The amount of SGLT1 mRNA tended to be higher $(P=0.1)$ in duodenal than in jejunal mucosa, whereas the mRNA level of GLUT2 did not differ between intestinal segments (Table 4). Neither SGLT1 nor GLUT2 mRNA levels were affected by diet.

Immunoblot in BBMV using SGLT1 and GLUT2 antibodies indicated specific bands at 70 and $55 \mathrm{kDa}$ in duodenal and jejunal mucosa, respectively. Examples of immunoblots of duodenal and jejunal BBMV for SGLT1 and GLUT2, respectively, are shown in Figure 1, panels A and B. The immunoblot for GLUT2 in crude cell membranes showed a specific band at $55 \mathrm{kDa}$ in duodenal and jejunal mucosa (Figure 1C). Protein contents of SGLT1 in BBMV and GLUT2 in BBMV

Table 3. Intake of DM, energy $\left(\mathrm{NE}_{\mathrm{L}}\right)$, protein, total and rumen-undegraded starch, and fat in cows fed diets containing high starch (HS) or low starch (LS) for 4 wk

\begin{tabular}{|c|c|c|c|c|c|c|}
\hline \multirow[b]{2}{*}{ Variable $^{1}$} & \multicolumn{2}{|c|}{ Group } & \multirow[b]{2}{*}{$\mathrm{SE}$} & \multicolumn{3}{|c|}{ ANOVA ( $P$-value $)$} \\
\hline & HS & LS & & Diet & Time & Diet $\times$ Time \\
\hline DMI, kg/d & 20.6 & 18.4 & 0.5 & 0.01 & 0.06 & 0.8 \\
\hline $\mathrm{CP}, \mathrm{kg} / \mathrm{d}$ & 3.5 & 3.41 & 0.08 & 0.5 & 0.06 & 0.8 \\
\hline Utilizable protein, ${ }^{2} \mathrm{~kg} / \mathrm{d}$ & 3.33 & 3.11 & 0.08 & 0.06 & 0.06 & 0.8 \\
\hline Starch, $\mathrm{kg} / \mathrm{d}$ & 4.94 & 2.21 & 0.09 & 0.001 & 0.1 & 0.7 \\
\hline Rumen-undegraded starch, ${ }^{2} \mathrm{~kg} / \mathrm{d}$ & 1.65 & 0.33 & 0.03 & 0.001 & 0.17 & 0.5 \\
\hline Crude fat, $\mathrm{kg} / \mathrm{d}$ & 0.45 & 1.1 & 0.02 & 0.001 & 0.11 & 0.6 \\
\hline $\mathrm{NE}_{\mathrm{L}},{ }^{2} \mathrm{MJ} / \mathrm{d}$ & 146 & 139 & 3.3 & 0.2 & 0.07 & 0.9 \\
\hline
\end{tabular}

${ }^{1}$ Values are LSM with pooled SE.

${ }^{2}$ German Society of Nutrition Physiology (2001). 
Table 4. Amount of mRNA and protein of sodium-dependent glucose co-transporter-1 (SGLT1) and facilitated glucose transporter (GLUT2) in duodenal and jejunal mucosa of cows fed diets containing high starch (HS) or low starch (LS) for $4 \mathrm{wk}^{1}$

\begin{tabular}{|c|c|c|c|c|c|c|}
\hline \multirow[b]{2}{*}{ Variable $^{2}$} & \multicolumn{2}{|c|}{ Group } & \multirow[b]{2}{*}{$\mathrm{SE}$} & \multicolumn{3}{|c|}{ ANOVA ( $P$-value $)$} \\
\hline & HS & LS & & Diet & Gut & Diet $\times$ Gut \\
\hline \multirow{2}{*}{\multicolumn{7}{|c|}{ mRNA amount, relative to $\beta$-actin expression }} \\
\hline & & & & \multicolumn{3}{|c|}{ SGLT1 } \\
\hline Duodenum & 0.44 & 0.62 & 0.15 & \multirow[t]{2}{*}{0.3} & \multirow[t]{2}{*}{0.11} & \multirow[t]{2}{*}{0.9} \\
\hline Jejunum & 0.21 & 0.36 & 0.15 & & & \\
\hline \multicolumn{7}{|l|}{ GLUT2 } \\
\hline Duodenum & 0.24 & 0.36 & 0.15 & \multirow[t]{2}{*}{0.2} & \multirow[t]{2}{*}{0.3} & \multirow[t]{2}{*}{0.6} \\
\hline Jejunum & 0.32 & 0.61 & 0.15 & & & \\
\hline \multirow{2}{*}{\multicolumn{7}{|c|}{ Protein amount, relative to internal standard }} \\
\hline SGLT1, apice & & & & & & \\
\hline Duodenum & 0.56 & 0.68 & 0.15 & \multirow[t]{2}{*}{0.9} & \multirow[t]{2}{*}{0.3} & \multirow[t]{2}{*}{0.5} \\
\hline Jejunum & 0.8 & 0.72 & 0.13 & & & \\
\hline \multicolumn{7}{|c|}{ GLUT2, apical vesicles } \\
\hline Duodenum & 3.2 & 2.23 & 1.17 & \multirow[t]{2}{*}{0.9} & \multirow[t]{2}{*}{0.8} & \multirow[t]{2}{*}{0.5} \\
\hline Jejunum & 2.67 & 3.36 & 1.13 & & & \\
\hline \multicolumn{7}{|c|}{ GLUT2, total membrane } \\
\hline Duodenum & 1.7 & 2.33 & 0.76 & \multirow[t]{2}{*}{0.8} & \multirow[t]{2}{*}{0.7} & \multirow[t]{2}{*}{0.5} \\
\hline Jejunum & 2.24 & 2.2 & 0.76 & & & \\
\hline
\end{tabular}

and crude membranes were not affected by diet or intestinal segment (Table 4).

Specific mRNA for PC, PEPCK, and G6Pase could be found in small intestinal mucosa of duodenum and jejunum. The amounts of PEPCK and G6Pase mRNA in small intestinal mucosa were not affected by intestinal segment or diet, but the abundance of PC mRNA tended to be higher in jejunum than in duodenum (Table 5).

\section{DISCUSSION}

\section{Glucose Transporter in Small Intestinal Mucosa}

The detection of SGLT1 mRNA and protein in small intestinal mucosa supports previous studies in cows and beef steers (Zhao et al., 1998; Rodriguez et al., 2004; Liao et al., 2010). The abundance of SGLT1 mRNA decreased in our study from duodenum to jejunum, whereas protein expression of SGLT1 indicated no gut site effect. These findings were in contrast to observations showing greater mRNA and protein expression in the jejunum than in the duodenum (Rodriguez et al., 2004; Liao et al., 2010). In addition, we could not find a diet effect for SGLT1 gene and protein expression when comparing HS with LS diet. Reasons for the lack of effects are presently unknown, but our findings may imply that the HS diet did not provide enough glucose for additional stimulating SGLT1 content in the small intestinal mucosa. Plasma glucose concentrations of HS and LS cows suggest differences in intestinal glucose uptake (Lohrenz et al., 2010). Obviously, SGLT1 regulation was not affected by the feeding conditions used in this study. On the other hand, it was surprising that SGLT1 content in small intestine was not downregulated by the LS diet, although significantly less starch and probably less glucose were available in the small intestine. Ruminants maintain SGLT1 mRNA and protein levels even though they consume less starch (Bauer et al., 1995). So far, upregulation of SGLT1 content and activity as well as transcriptional regulation in ruminants have mostly been described in response to luminal infusion of glucose (Shirazi-Beechey et al., 1995; Bauer et al., 2001b; Vayro et al., 2001). Recent findings in beef steers indicated an increase of SGLT1 mRNA in duodenal mucosa after ruminal starch infusion, but no changes were seen in jejunal mucosa or when starch was infused into the abomasum (Liao et al., 2010). Starch administration often failed to stimulate glucose transport by SGLT1 in beef steers (Bauer et al., 2001a; Rodriguez et al., 2004), indicating limitations in small intestinal glucose uptake in ruminants (Harmon and McLeod, 2001). Therefore, the capacity for upregulation of intestinal glucose absorption and glucose transporter seems to be limited. This might be due to a limited capacity for small intestinal starch digestion in ruminants (Nocek and Tamminga, 1991), resulting in less intestinal glucose to stimulate glucose transporter, or due to reduced starch digestion with increasing duodenal starch availability (Matthé et al., 2000; Huntington et al., 2006). 
Transcripts of GLUT2 in the small intestinal mucosa were expected based on previous reports in cattle (Zhao et al., 1993; Liao et al., 2010). Studies in beef steers indicated higher GLUT2 mRNA levels in jejunal than in duodenal epithelia (Liao et al., 2010), and although we have seen numerically higher mRNA levels in jejunal mucosa, GLUT2 mRNA levels in duodenal and jejunal mucosa were not different in our study. Ruminal or abomasal starch infusion in beef steers did not affect GLUT2 mRNA content in duodenal and jejunal epithelia (Liao et al., 2010). These findings agree with our data presented here that diets largely differing in intestinal starch supply do not affect GLUT2 gene expression. On the other hand, intestinal GLUT2 mRNA is regulated by luminal factors in rats (Cui et al., 2003).

Interestingly, we could find GLUT2 protein in the BBMV of duodenal and jejunal mucosa; GLUT2 protein was also found in BBMV of pig and sheep (Kellett et al., 2008). This might point to a role for GLUT2 in apical glucose absorption, as was recently asserted for rats (Kellett and Helliwell, 2000; Au et al., 2002). The presence of GLUT2 protein in BBMV as well as in crude membranes was not regulated by diet and did not differ between gut segments.

\section{Gene Expression of Gluconeogenic Enzymes in the Small Intestinal Mucosa}

We identified gene expression of the enzymes PC, PEPCK, and G6Pase in intestinal mucosa of duodenum and jejunum, as is seen in other species (Battezzati, 2010); to our knowledge this is the first report in ruminants. Compared with hepatic PC mRNA, intestinal PC mRNA abundance was similar or higher, but abundance of PEPCK and G6Pase mRNA was much lower in intestinal mucosa than in liver (Lohrenz et al., 2010). Although we have not measured protein levels and enzyme activities of these enzymes in intestinal mucosa, we doubt there is a net gluconeogenic activity in intestinal mucosa of dairy cows. The very low mRNA levels of G6Pase in intestinal mucosa compared with liver support this suggestion. Comparable mRNA concentrations of PC in liver and intestinal mucosa probably resulted from other metabolic pathways such as the citric acid cycle and amino acid synthesis, where PC is also involved (Aschenbach et al., 2010). Nevertheless, the significance of intestinal gluconeogenic activity under various physiological or pathophysiological conditions is a topic on ongoing discussion, based on data mainly from studies in rodents (Habold et al., 2005; Mithieux, 2005; Previs et al., 2009; Battezzati, 2010).

In addition, we did not find any diet effect on mRNA abundance of these enzymes involved in gluconeogenesis, whereas G6Pase in liver was higher in HS than
A)

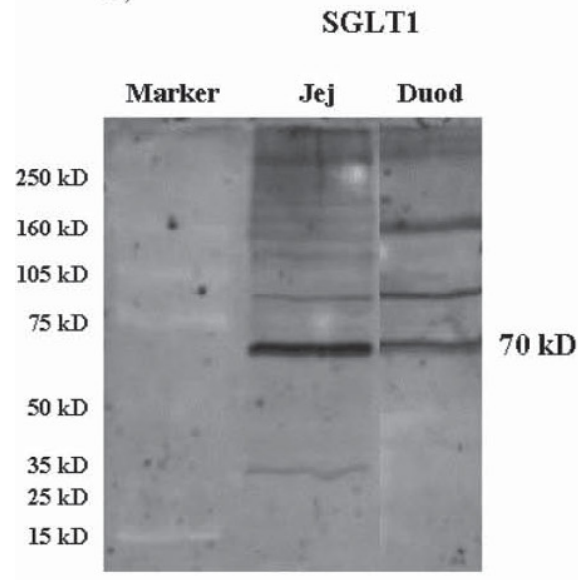

B)

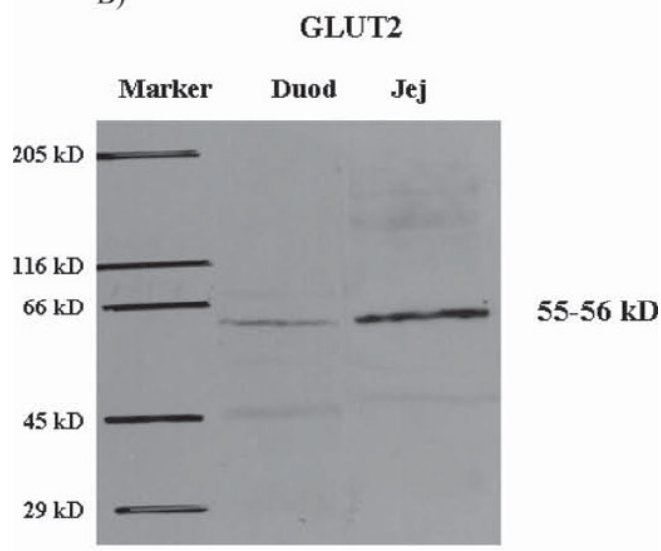

C)

\section{GLUT2}

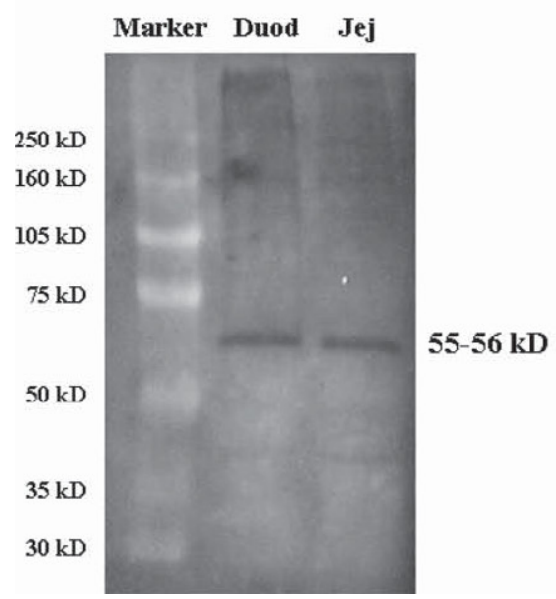

Figure 1. Immunoblot of sodium-dependent glucose co-transporter-1 (SGLT1; A) and facilitated glucose transporter (GLUT2; B) protein in duodenum (Duod) and jejunum (Jej) brush border membrane vesicles, and of GLUT2 protein in duodenal and jejunal cell membranes (C). The markers indicate bands at about $70 \mathrm{kDa}$ (SGLT1) and $55 \mathrm{kDa}$ (GLUT2), respectively. Lanes for SGLT1 protein expression in duodenal and jejunal mucosa (A) were from the same blot but rearranged to compare duodenal and jejunal protein expression of SGLT1 directly. 
Table 5. Amount of mRNA of pyruvate carboxylase (PC), cytosolic phosphoenolpyruvate carboxykinase (PEPCK), and glucose-6-phosphatase (G6Pase) in duodenal and jejunal mucosa of cows fed diets containing high starch (HS) or low starch (LS) for $4 \mathrm{wk}^{1}$

\begin{tabular}{|c|c|c|c|c|c|c|}
\hline \multirow{2}{*}{$\begin{array}{l}\text { mRNA amount, } \\
\text { relative to } \\
\beta \text {-actin expression }{ }^{2}\end{array}$} & \multicolumn{2}{|c|}{ Group } & \multirow[b]{2}{*}{ SE } & \multicolumn{3}{|c|}{ ANOVA ( $P$-value $)$} \\
\hline & HS & LS & & Diet & Gut & Diet $\times$ Gut \\
\hline \multicolumn{7}{|l|}{$\mathrm{PC}$} \\
\hline Duodenum & 0.5 & 0.32 & 0.44 & 0.8 & 0.09 & 0.9 \\
\hline Jejunum & 1.28 & 1.26 & 0.44 & & & \\
\hline \multicolumn{7}{|l|}{ PEPCK } \\
\hline Duodenum & 0.05 & 0.053 & 0.015 & 0.6 & 0.15 & 0.8 \\
\hline Jejunum & 0.021 & 0.032 & 0.014 & & & \\
\hline \multicolumn{7}{|l|}{ G6Pase } \\
\hline Duodenum & 0.071 & 0.08 & 0.037 & 1 & 0.7 & 0.8 \\
\hline Jejunum & 0.1 & 0.085 & 0.037 & & & \\
\hline
\end{tabular}

${ }^{1}$ Quantification of mRNA was performed by relative expression by the arithmetic equation $\mathrm{R}=2^{-\Delta \Delta \mathrm{Ct}}$ using $\beta$-actin as reference gene transcript as described in Materials and Methods (Pfaffl, 2001).

${ }^{2}$ Values are LSM with pooled SE.

in LS cows (Lohrenz et al., 2010). If HS and LS cows differ in luminal glucose availability in the small intestine, this should have an effect on mRNA abundance of gluconeogenic enzymes in the intestinal mucosa, which was not the case in our study. However, less is known of the metabolic fate of intestinal glucose coming from the luminal side, and data on the significance of glucose as intestinal fuel are inconsistent (Okine et al., 1995; Oba et al., 2004; Reynolds, 2006). The slightly greater gene expression of PC in jejunal mucosa was surprising; PC catalyzes the formation of oxaloacetate from pyruvate that could originate from lactate or AA such as Ala and Gln. Absorption of AA might be higher in jejunum than in duodenum and could contribute to greater AA abundance in jejunal mucosa. In particular, Gln is used as energy fuel in enterocytes (Mithieux, 2005) and could have affected PC gene expression.

\section{Effect of Findings on Starch Digestion in Dairy Cows}

It is unquestionable that intestinal starch digestion and intestinal glucose absorption have a significant effect on energy supply in dairy cows (Breves and Wolffram, 2006; Huntington et al., 2006; Reynolds, 2006). Nevertheless, we could not find differences in glucose transporter gene and protein expression as well as gene expression of gluconeogenic enzymes in the small intestine, although diets fed in our study largely differed in starch content and ruminal undegraded starch (Nocek and Tamminga, 1991; DLG, 2008). Studies on hepatic and systemic glucose metabolism in HS and LS cows indicated diet effects on endocrine regulation of glucose metabolism and on gene expression of gluconeogenic enzymes in liver as well as differences in plasma triglyceride and NEFA concentrations (Hammon et al., 2008; Lohrenz et al., 2010). We assume that differences in systemic glucose metabolism were probably not a result of elevated intestinal glucose absorption in HS-fed cows. Differences in enteral glucose were possibly too small to influence small intestinal glucose transporters. These changes on glucose transporters are seen in monogastric animals as well as partly in ruminants when glucose was infused at various sites of the gastrointestinal tract (Shirazi-Beechey et al., 1995; Dyer et al., 2003; Kellett et al., 2008). Therefore, the question remains whether starch feeding and especially providing large amounts of ruminally undegraded starch can really modulate glucose absorptive capacity in dairy cows under practical conditions (Matthé et al., 2000; Harmon and McLeod, 2001; Reynolds, 2006).

In conclusion, our investigations on glucose transporters in the small intestine of dairy cows did not show significant diet regulation when common TMR that differed in the amount of available starch in the gut were fed. Although HS diets may lead to an elevated intestinal glucose absorption in ruminants, the number of glucose transporters obviously does not change to support glucose absorption. Further investigations should focus on diet effects that might bring about an increase in glucose absorption activity, even though the number of glucose transporters remains unchanged.

\section{ACKNOWLEDGMENTS}

The authors gratefully acknowledge the laboratory staff (Claudia Reiko, Helga Schott, and Brigitte Waischnow) and animal caretakers (Dirk Oswald) of the Research Unit Nutritional Physiology as well as Gunter Klautschek and the Animal Experimental Unit of the FBN for excellent technical assistance. The Rinderzuchtverband Mecklenburg-Vorpommern (RMV) is acknowledged for logistic support with selection of 
cows. Hajenol was provided by Harles und Jentzsch (Uetersen, Germany). Protected soybean meal was provided by Wulfamast (Dinklage-Wulfenau, Germany). The study was supported by a grant of the Deutsche Forschungsgemeinschaft, Bonn, to H. M. S. and C. C. M. (SE 326/13-2), and the core budget of the FBN.

\section{REFERENCES}

Aschenbach, J. R., N. B. Kristensen, S. S. Donkin, H. M. Hammon, and G. B. Penner. 2010. Gluconeogenesis in dairy cows: The secret of making sweet milk from sour dough. IUBMB Life 62:869-877.

Au, A., A. Gupta, P. Schembri, and C. I. Cheeseman. 2002. Rapid insertion of GLUT2 into the rat jejunal brush-border membrane promoted by glucagon-like peptide 2. Biochem. J. 367:247-254.

Battezzati, A. 2010. Non-hepatic glucose production: An update. Pages 155-161 in Energy and Protein Metabolism and Nutrition. G. M. Crovetto, ed. Wageningen Academic Publishers, Wageningen, the Netherlands.

Bauer, M. L., D. L. Harmon, D. W. Bohnert, A. F. Branco, and G B. Huntington. 2001a. Influence of $\alpha$-linked glucose on sodiumglucose cotransport activity along the small intestine in cattle. J. Anim. Sci. 79:1917-1924.

Bauer, M. L., D. L. Harmon, K. R. McLeod, and G. B. Huntington 1995. Adaptation to small intestinal starch assimilation and glucose transport in ruminants. J. Anim. Sci. 73:1828-1838.

Bauer, M. L., D. L. Harmon, K. R. McLeod, and G. B. Huntington. 2001b. Influence of $\alpha$-linked glucose on jejunal sodium-glucose cotransport activity in ruminants. Comp. Biochem. Physiol. A Mol. Integr. Physiol. 129:577-583.

Bradford, M. M. 1976. A rapid and sensitive method for the quantification of microgram quantities of protein utilizing the principle of protein-dye binding. Anal. Biochem. 72:248-254.

Breves, G., and S. Wolffram. 2006. Transport systems in the epithelia of the small and large intestines. Pages 139-154 in Ruminant Physiology: Digestion, Metabolism and Impact of Nutrition on Gene Expression, Immunology and Stress. K. Sejrsen, T. Hvelplund, and M. O. Nielsen, ed. Wageningen Academic Publishers, Wageningen, the Netherlands.

Cui, X. L., L. Jiang, and R. P. Ferraris. 2003. Regulation of rat intestinal GLUT2 mRNA abundance by luminal and systemic factors. Biochim. Biophys. Acta 1612:178-185.

DLG. 2008. Strukturbeständigkeit für die silierte MaisproduktionStruktur- und Kohlenhydratversorgung der Milchkuh. DLG-Informationen. DLG-Verlag, Frankfurt, Germany.

Drackley, J. K., T. R. Overton, and G. N. Douglas. 2001. Adaptations of glucose and long-chain fatty acid metabolism in liver of dairy cows during the periparturient period. J. Dairy Sci. 84(ESuppl.):E100-E112.

Duske, K., H. M. Hammon, A. K. Langhof, O. Bellmann, B. Losand, K. Nürnberg, G. Nürnberg, H. Sauerwein, H. M. Seyfert, and C. C. Metges. 2009. Metabolism and lactation performance in dairy cows fed a diet containing rumen-protected fat during the last twelve weeks of gestation. J. Dairy Sci. 92:1670-1684.

Dyer, J., S. Vayro, T. P. King, and S. P. Shirazi-Beechey. 2003. Glucose sensing in the intestinal epithelium. Eur. J. Biochem. 270:3377-3388.

Fujita, M., H. Matsui, K. Nagano, and M. Nakao. 1971. Asymmetric distribution of ouabain-sensitive ATPase activity in rat intestinal mucosa. Biochim. Biophys. Acta 233:404-408.

German Society of Nutrition Physiology. 2001. Ausschuss für Bedarfsnormen der Gesellschaft für Ernährungsphysiologie, No. 8. Empfehlungen zur Energie- und Nährstoffversorgung der Milchkühe und Aufzuchtrinder (Recommended energy and nutrient supply for dairy cows and growing cattle). DLG-Verlag, Frankfurt am Main, Germany.

Habold, C., C. Foltzer-Jourdainne, Y. Le Maho, J. H. Lignot, and H. Oudart. 2005. Intestinal gluconeogenesis and glucose transport according to body fuel availability in rats. J. Physiol. 566:575-586.
Hammon, H. M., C. C. Metges, P. Junghans, F. Becker, O. Bellmann, F. Schneider, G. Nürnberg, P. Dubreuil, and H. Lapierre. 2008. Metabolic changes and net portal flux in dairy cows fed a ration containing rumen-protected fat as compared to a control diet. J. Dairy Sci. 91:208-217.

Hammon, H. M., G. Stürmer, F. Schneider, A. Tuchscherer, H. Blum, T. Engelhard, A. Genzel, R. Staufenbiel, and W. Kanitz. 2009. Performance and metabolic and endocrine changes with emphasis on glucose metabolism in high-yielding dairy cows with high and low fat content in liver after calving. J. Dairy Sci. 92:1554-1566.

Harmon, D. L., and K. R. McLeod. 2001. Glucose uptake and regulation by intestinal tissues: Implications and whole-body energetics. J. Anim. Sci. 79(E. Suppl.):E59-E72.

Huntington, G. B. 1997. Starch utilization by ruminants: From basics to the bunk. J. Anim. Sci. 75:852-867.

Huntington, G. B., D. L. Harmon, and C. J. Richards. 2006. Sites, rates, and limits of starch digestion and glucose metabolism in growing cattle. J. Anim. Sci. 84(E. Suppl.):E14-E24.

Janes, A. N., T. E. Weeks, and D. G. Armstrong. 1985. Absorption and metabolism of glucose by the mesenteric-drained viscera of sheep fed on dried-grass or ground, maize-based diets. Br. J. Nutr. 54:449-458.

Kellett, G. L., E. Brot-Laroche, O. J. Mace, and A. Leturque. 2008. Sugar absorption in the intestine: The role of GLUT2. Annu. Rev. Nutr. 28:35-54.

Kellett, G. L., and P. A. Helliwell. 2000. The diffusive component of intestinal glucose absorption is mediated by the glucose-induced recruitment of GLUT2 to the brush-border membrane. Biochem. J. $350: 155-162$.

Laemmli, U. K. 1970. Cleavage of structural proteins during the assembly of the head of bacteriophage T4. Nature 227:680-685.

Larsen, M., and N. B. Kristensen. 2009. Effects of abomasal glucose infusion on splanchnic and whole-body glucose metabolism in periparturient dairy cows. J. Dairy Sci. 92:1071-1083.

Liao, S. F., D. L. Harmon, E. S. Vanzant, K. R. McLeod, J. A. Boling, and J. C. Matthews. 2010. The small intestinal epithelia of beef steers differentially express sugar transporter messenger ribonucleic acid in response to abomasal versus ruminal infusion of starch hydrolysate. J. Anim. Sci. 88:306-314.

Lohrenz, A. K., K. Duske, F. Schneider, K. Nürnberg, B. Losand, H. M. Seyfert, C. C. Metges, and H. M. Hammon. 2010. Milk performance and glucose metabolism in dairy cows fed rumen-protected fat during mid-lactation. J. Dairy Sci. 93:5867-5876.

Matthé, A., P. Lebzien, and G. Flachowsky. 2000. On the relevance of bypass-starch for the glucose supply of high-yielding dairy cows. Übers. Tierernähr. 28:1-64.

Mills, J. A. N., J. France, and J. Dijkstra. 1999. A review of starch digestion in the lactating dairy cow and proposals for a mechanistic model: 2. Postruminal starch digestion and small intestinal glucose absorption. J. Anim. Feed Sci. 8:451-481.

Mithieux, G. 2005. The new functions of the gut in the control of glucose homeostasis. Curr. Opin. Clin. Nutr. Metab. Care 8:445-449.

Moe, A. J., P. A. Pocius, and C. E. Polan. 1985. Isolation and characterization of brush border membrane vesicles from bovine small intestine. J. Nutr. 115:1173-1179.

Naumann, C., and R. Bassler. 1993. Die chemische Untersuchung von Futtermitteln. VDLUFA-Verlag, Darmstadt, Germany.

Nocek, J. E., and S. Tamminga. 1991. Site of digestion of starch in the gastrointestinal tract of dairy cows and its effect on milk yield and composition. J. Dairy Sci. 74:3598-3629.

Nozière, P., I. Ortigues-Marty, C. Loncke, and D. Sauvant. 2010. Carbohydrate quantitative digestion and absorption in ruminants: From feed starch and fibre to nutrients available for tissue. Animal 4:1057-1074.

Oba, M., R. L. Baldwin VI, and B. J. Bequette. 2004. Oxidation of glucose, glutamate, and glutamine by isolated ovine enterocytes in vitro is decreased by the presence of other metabolic fuels. J. Anim. Sci. 82:479-486.

Okine, E. K., D. R. Glimm, J. R. Thompson, and J. J. Kennelly. 1995. Influence of stage of lactation on glucose and glutamine me- 
tabolism in isolated enterocytes from dairy cattle. Metabolism 44:325-331.

Pfaffl, M. W. 2001. A new mathematical model for relative quantification in real-time RT-PCR. Nucleic Acids Res. 29:e45.

Previs, S. F., D. Z. Brunengraber, and H. Brunengraber. 2009. Is there glucose production outside of the liver and kidney? Annu. Rev. Nutr. 29:43-57.

Rasmussen, R. 2001. Quantification on the LightCycler. Pages 21-34 in Rapid Cycle Real-Time PCR, Methods and Applications. S. Meuer, C. Wittwer, K. Nakagawara, ed. Springer Press, Heidelberg, Germany.

Reynolds, C. K. 2006. Production and metabolic effects of site of starch digestion in dairy cattle. Anim. Feed Sci. Technol. 130:78-94.

Rodriguez, S. M., K. C. Guimaraes, J. C. Matthews, K. R. Mc, R. L. Leod, V. I. Baldwin, and D. L. Harmon. 2004. Influence of abomasal carbohydrates on small intestinal sodium-dependent glucose cotransporter activity and abundance in steers. J. Anim. Sci. $82: 3015-3023$.

SAS Institute. 2004. SAS/STAT 9.1 User's Guide. SAS Institute Inc., Cary, NC.

Schröder, B., and G. Breves. 1996. Mechanism of phosphate uptake into brush border membrane vesicles from goat jejunum. J. Comp. Physiol. B 166:230-240.
Shirazi-Beechey, S. P., I. S. Wood, J. Dyer, D. Scott, and T. P. King. 1995. Intestinal sugar transport in ruminants. Pages 117-133 in Ruminant Physiology: Digestion, Metabolism, Growth and Reproduction. W. von Engelhardt, S. Leonhard-Marek, G. Breves, and D. Giesecke, ed. Ferdinand Enke Verlag, Stuttgart, Germany.

Vayro, S., I. S. Wood, J. Dyer, and S. P. Shirazi-Beechey. 2001. Transcriptional regulation of the ovine intestinal $\mathrm{Na}^{+} /$glucose cotransporter SGLT1 gene: Role of HNF-1 in glucose activation of promoter function. Eur. J. Biochem. 268:5460-5470.

Voigt, J., S. Kuhla, K. Gaafar, M. Derno, and H. Hagemeister. 2006. Digestibility of rumen protected fat in cattle. Slovak J. Anim. Sci. 39:16-19.

Zhao, F. Q., D. R. Glimm, and J. J. Kennelly. 1993. Distribution of mammalian facilitative glucose transporter messenger RNA in bovine tissues. Int. J. Biochem. 25:1897-1903.

Zhao, F. Q., J. Okine, C. I. Cheeseman, S. P. Shirazi-Beechey, and J. J. Kennelly. 1998. Glucose transporter expression in lactating bovine gastrointestinal tract. J. Anim. Sci. 76:2921-2929. 